Volume I4 Number 5 November 2008

Pages 473-598 


\title{
RE-CONCEIVING THE ARTFUL IN MANAGEMENT DEVELOPMENT AND EDUCATION
}

\author{
Edited by \\ CHERYL KERR \\ Centre for Learning Innovation \\ Faculty of Education \\ Queensland University of Technology, Australia \\ LOTTE DARS $\varnothing$ \\ The Creative Alliance \\ Learning Lab Denmark \\ Danish University of Education
}

ISBN 978-0-9775742-6-1

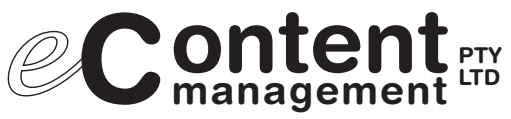

Sydney - Amsterdam • Palo Alto 
ISBN 978-0-9775742-6-1

$\mathrm{ii}+126$ pages softcover

\author{
Published in Australia by: \\ eContent Management Pty Ltd \\ PO Box 1027 \\ Maleny, QLD 4552 \\ Australia \\ Tel. +61-(0)7-5435 2900 \\ Fax: +61-(0)7-5435 2911 \\ www.e-contentmanagement.com
}

ABN 87091432567

Affiliates in: Sydney, Amsterdam, Palo Alto

A special issue of the Journal of Management \& Organization:

Volume 14 Issue 5 (November 2008) ISSN 1833-3672

\title{
Journal of Management \& Organization
}

Re-conceiving the artful in management development and education

Bibliography

ISBN 987-0-9775742-6-1

1. Artful management. 2. Management education. 3. Management development.

4. Pedagogical learning. 5. Creativity. 6. Innovation. 7. Artful classroom.

8. Organization aesthetics. 9. Art economics

I. Kerr, Cheryl. II. Darsø, Lotte.

[Series: Journal of Management \& Organization (Maleny QLD): vol. 14_5]

(C) 2008, eContent Management Pty Ltd

This publication is copyright. Other than for purposes of and subject to the conditions prescribed under the Copyright Act, no part of it may in any form or by any means (electronic, mechanical, microcopying, photocopying, recording or otherwise) be reproduced, stored in a retrieval system or transmitted without prior written permission. Inquiries should be addressed to the Publisher at: info@e-contentmanagement.com

Publisher: James H Davidson, eContent Management Pty Ltd (Queensland)

Desk Editor: Jenny Gibson, eContent Management Pty Ltd (Queensland)

Desktop Publisher: Kim Webber, Southern Star Design (New South Wales)

Printed in Malaysia by Vivar Printing Sdn Bhd, Selangor D.E. (Malaysia) 


\title{
JOURNAL OF MANAGEMENT \& ORGANIZATION
}

\author{
Journal of the Australian and New Zealand Academy of Management
}

Re-conceiving the Artful in Management Development and Education

Edited by Cheryl Kerr and Lotte Darsø

ISBN 978-0-9775742-6-1

\section{CONTENTS}

\section{Volume 14 • ISSUe 5 • NOVember 2008}

474 INTRODUCTION - Re-conceiving the artful in management development and education - Cheryl Kerr and Lotte Darsø

481 REFEREE ACKNOWLEDGMENT

482 PROLOGUE - Interview with Margaret Wheatley, 7 September 2008 - Lotte Dars $\varnothing$

486 Pedagogical learnings for management education: Developing creativity and innovation - Cheryl Kerr and Cathryn Lloyd

504 An Artful Learning Framework for organizations - Glenys Drew

521 Finding beauty in the banal: An exploration of service work in the artful classroom - Ralph Bathurst, Janet Sayers and Nanette Monin

535 Realizing the artful in management education and development: Smoldering examples from the Burning Man Project - J Duane Hoover

548 Directing creativity: The art and craft of creative leadership - Piers Ibbotson and Lotte Darsø

560 Dances of leadership: Bridging theory and practice through an aesthetic approach - Arja Ropo and Erika Sauer

573 A Case Study of Arteconomy: Building a bridge between art and enterprise: Belgian businesses stimulate creativity and innovation through art - Herman van den Broeck, Eva Cools and Tine Maenhout

588 EPILOGUE - Art and Business for European Identity: Illustrating meaningful evolutions in business through classical masterpieces of music (Case Study)

- Cheryl Kerr and Lotte Darsø

593 Managing the Unexpected: Resilient Performance in an Age of Uncertainty KE Weick and KM Sutcliffe. Reviewer: David M Clarke

594 A Very Short, Fairly Interesting and Reasonably Cheap Book About Studying Leadership - B Jackson and K Parry. Reviewer: Michael Muchiri

596 Organizational Jazz: Extraordinary Performance through Extraordinary Leadership - D Napoli, AM Whiteley and KS Johansen. Reviewer: Paul Waight

ISSN 1833-3672 • www.jmanorg.com

Published by@COntent Pri SAN 902-4964

PO Box 1027, Maleny, QLD 4552, Australia www.e-contentmanagement.com
2008 @ e Content Management Pty Ltd Aggregated in ProQuest; Abstracted/indexed in Thomson Scientific SSCI, PsycINFO, EBSCO Publishing, Cengage, EBSCOhost, Scopus, SwetsWise, eBrary, MyiLibrary, NetLibrary, CSA Illustrata, APAIS, Questia and Atypon; listed in Cabell's and Ulrich's Periodicals Directories and DEST Register of Refereed Journals. Special issues appear as eBooks on Ebook Library. Registered with the Copyright Agency Ltd: www.copyright.com.an 